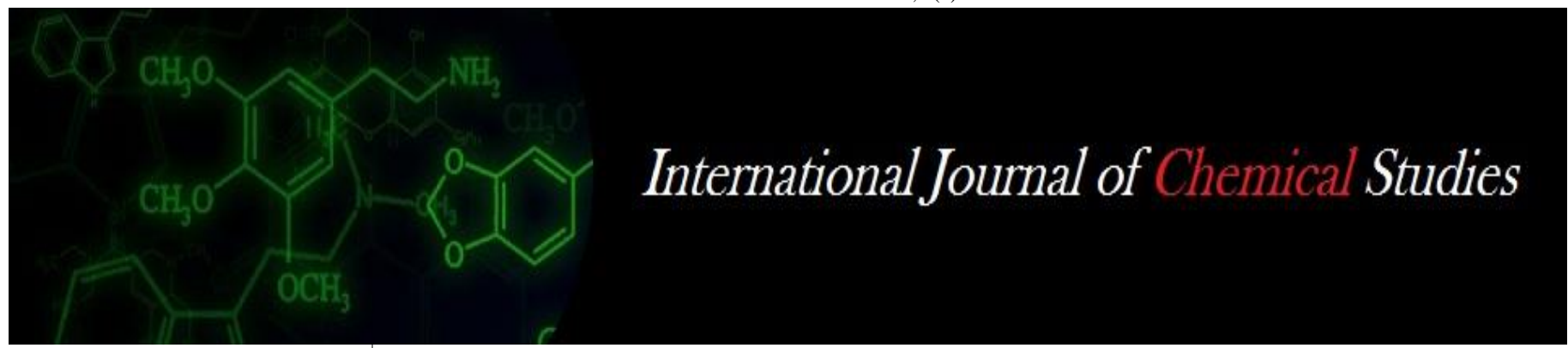

P-ISSN: 2349-8528

E-ISSN: 2321-4902

www.chemijournal.com

IJCS 2021; 9(1): 1005-1007

(C) 2021 IJCS

Received: 07-10-2020

Accepted: 15-12-2020

\section{Bhavik K Pate}

Main Cotton Research Station MCRS, Navsari Agricultural

University (NAU), Surat,

Gujarat, India

Prashant B Sandipan

Main Cotton Research Station MCRS, Navsari Agricultural

University (NAU), Surat,

Gujarat, India

\section{RK Patel}

Krushi Vigyan Kendra, Navsari Agricultural University (NAU),

Surat, Gujarat, India

SK Chawada

Krushi Vigyan Kendra, Navsari Agricultural University (NAU), Surat, Gujarat, India
Corresponding Author: Bhavik K Patel

Main Cotton Research Station MCRS, Navsari Agricultural

University (NAU), Surat,

Gujarat, India

\title{
Screening of different fungicides and biocontrol agents against $F$ usarium oxysporum f. sp. vasinfectum (FOV) under pot condition
}

\author{
Bhavik K Patel, Prashant B Sandipan, RK Patel and SK Chawada
}

DOI: https://doi.org/10.22271/chemi.2021.v9.i1n.11358

\section{Abstract}

Cotton (Gossypium spp.) is one of the most important fiber crops playing a key role in economic and social scenario of the globe. It is oldest among the commercial crops of the world providing fiber for clothing of the mankind. A pot experiment was conducted to test the efficacy of the fungicides and bioagents under in vitro condition. Among these, soil drenching with $0.20 \%$ pyraclostrobin $5 \%+$ mitiram $55 \%(84.07 \%)$ proved effective which is followed by $0.20 \%$ captan $70 \%+$ hexaconazole $5 \%(80.52 \%)$ in managing the wilt of cotton.

Keywords: Screening, pot, FOV, wilt

\section{Introduction}

Cotton production has great importance in India due to its economic and social impact and because it plays an important role in crop rotation, production and others. Cotton is one of the most important fiber and cash crop of India which plays a significant and dominant role in the industrial and agricultural economy of our country. It provides the basic raw materials such as cotton fiber to cotton textile industry. In India, there are ten major cotton growing states which are divided into three zones, viz., North zone, Central zone and South zone. North zone consists of Punjab, Haryana and Rajasthan. Central zone includes Madhya Pradesh, Maharashtra and Gujarat. South zone comprises Andhra Pradesh, Telangana, Karnataka and Tamil Nadu. The crop is affected by abundant pests, diseases and weeds etc causing serious economic losses in a crop. The low productivity of cotton is mainly due to high incidence of insect pests and diseases caused by fungal, bacterial and viral pathogens. Among foliar diseases; Bacterial blight, Alternaria leaf spot and grey mildew are the most important and now the Corynespora is also taking place. Similarly, the soil borne diseases is also important as Wilt, Root rot and Para wilt (Physiological disorder) etc. In North India, the cotton leaf curl disease $(\mathrm{CLCuD})$ caused by gemini virus and transmitted by whitefly Bemisia tabaci (Gennadius) has become a serious threat to cotton cultivation due to development of new recombinant strains and introduction of a number of susceptible $B t$ cotton hybrids in north zone (Monga et al., 2011) ${ }^{[6]}$. In India, foliar diseases (fungal, bacterial and viral boll rot) have been estimated to cause yield losses up to 20 to $30 \%$ (Mayee and Mukewar, 2007) ${ }^{[4]}$. Under favourable conditions, losses to the tune of $26.59 \%$ (Monga et al., 2013) ${ }^{[5]}$ and $38.23 \%$ (Bhattiprolu and Prasada Rao, 2009) ${ }^{[1]}$ were recorded due to fungal diseases, leaf spot/blight caused by Alternaria macrospora Zimm. So in this context, alternative products for cotton disease management need to be developed. In this experiment, biocontrol agents along with the fungicides and combi products of fungicides were tested in the pot condition to find out promising options for alternative and sustainable disease management.

\section{Material and Method}

A pot experiment was conducted to test the effectiveness of fungicide and bioagents during its respective tests. The fungicide viz., mancozeb, thiram, propiconazole, carbendazim, pyraclostrobin + mitiram, captan + hexaconazole and antagonists viz., Trichoderma harzianum and $T$. viride were tested in pots separately for the management of the wilt of cotton under net house condition. 
The cotton seeds (GN Cot. 25) were treated with respective fungicide and bioagents whereas control with only distilled water. The drenching was initiated at the time of appearance of disease.

\section{Design: CRD \\ Repetition: 3}

Treatments: Two biocontrol agents, two systemic, two non systemic and two combiproducts were tested along with control.

Method: Seed treatment and soil drenching of given respective treatments. For soil inoculation, the fungus was multiplied on sand maize meal medium (SMMM) for preparation of mass inoculums in the laboratory. It was prepared in $250 \mathrm{ml}$ flasks using $90 \mathrm{~g}$ fine sieved sand, $10 \mathrm{~g}$ of maize meal and $20 \mathrm{ml}$ of distilled water just enough to moisten the mixture properly. The medium in flasks were then sterilized in autoclave at $15 \mathrm{lb}$ psi $\left(1.036 \mathrm{~kg} / \mathrm{cm}^{2}\right)$ for 30 minutes for three consecutive days. These flasks were inoculated with $5 \mathrm{~mm}$ mycelia disc of actively growing fungal culture and incubated at $27 \pm 2^{\circ} \mathrm{C}$ in an incubator for ten days. After ten days, the mycelium covered entire surface of medium. The culture was then used for inoculation. Each pot were sown with the five geminated healthy cotton seeds and then placed in a net house and after 30 days keeping one plant and other plants were removed. The cotton plants were irrigated as and when required and required quantity of fertilizer was added in the pot for proper growth and development. Inoculum of the said pathogen was applied in the soil at a rate of $10 \mathrm{~g} / \mathrm{kg}$ of soil (Elsalam et al., 2014) ${ }^{[2]}$. A control treatment was maintained without inoculum. Observation on per cent disease incidence was recorded by using following formula given by Wheeler (1969) ${ }^{[7]}$.

\footnotetext{
Number of infected plants/pot

PDI = --------------------------------X 100

Total number of plants/pot
}

Table 1: List of fungicides and biocontrol agents tested against Fusarium oxysporum f. sp. vasinfectum in pot condition

\begin{tabular}{|c|c|c|}
\hline Treat. No. & Fungicides and Biocontrol agents & Conc. (\%) \\
\hline $\mathrm{T}_{1}$ & Mancozeb (75WP) & 0.30 \\
\hline $\mathrm{T}_{2}$ & Thiram (75WP) & 0.30 \\
\hline $\mathrm{T}_{3}$ & Propiconazole (25EC) & 0.025 \\
\hline $\mathrm{T}_{4}$ & Carbendazim (50WP) & 0.005 \\
\hline $\mathrm{T}_{5}$ & Pyraclostrobin 5\% + Mitiram 55\% & 0.2 \\
\hline $\mathrm{T}_{6}$ & Captan 50\% + Hexaconazole 5\% & 0.2 \\
\hline $\mathrm{T}_{7}$ & Trichoderma harzianum & 5 \\
\hline $\mathrm{T}_{8}$ & Trichoderma viride & 5 \\
\hline $\mathrm{T}_{9}$ & Control & \\
\hline
\end{tabular}

\section{Result and Discussion}

With aim to find out an effective integration of various methods for the management of cotton wilt, a pot culture experiment was carried out.

The data presented in Table 2 and depicted in Plate 1 with Fig. 1 revealed that wilt incidence was observed significantly lower in all the treatments. Among these, pyraclostrobin 5\% + mitiram $55 \%$ proved 84.07 per cent effectiveness in managing the wilt disease at $0.20 \%$ and it was statistically significant over the control. Next best treatment in order of merit was captan $70 \%+$ hexaconazole $5 \%(82.52 \%)$ at $0.20 \%$, carbendazim (50WP) $(78.32 \%)$ at $0.005 \%$, propiconazole (25EC) $(73.01 \%)$ at $0.025 \%$ over control which was followed by Trichoderma harzianum $(67.25 \%)$ at $5 \%$ concentration.

Per cent wilt incidence was minimum when the soil was drenched with $0.20 \%$ pyraclostrobin $5 \%+$ mitiram $55 \%$ $(12.00 \%)$, the next best results were found with the treatment of $0.20 \%$ captan $50 \%$ + hexaconazole $5 \%$ (14.67\%), $0.005 \%$ carbendazim (16.33\%), $0.025 \%$ propiconazole $(20.33 \%)$ and $5 \%$ Trichoderma harzianum $(24.67 \%)$, while remaining other treatments showed more than $50 \%$ disease control of wilt. These results are in agreement with the results obtained by Kushawah (2015) ${ }^{[3]}$ who reported that pyraclostrobin $5 \%+$ mitiram $55 \%$ at $0.20 \%$ proved effective in control of wilt of cluster bean in pot condition.

Table 2: Testing of fungicides and biocontrol agents in pot condition against Fusarium wilt of cotton

\begin{tabular}{|c|c|c|c|c|}
\hline Sr. No. & Fungicides and Biocontrol agents & Conc. & Wilt incidence on plant (\%) & Disease control over check (\%) \\
\hline $\mathrm{T}_{1}$ & Mancozeb (75\% WP) & $0.30 \%$ & $5.582^{*}(30.67)^{* *}$ & 59.28 \\
\hline $\mathrm{T}_{2}$ & Thiram (75\% WP) & $0.30 \%$ & $5.275(27.33)$ & 63.71 \\
\hline $\mathrm{T}_{3}$ & Propiconazole (25\% EC) & $0.025 \%$ & $4.563(20.33)$ & 73.01 \\
\hline $\mathrm{T}_{4}$ & Carbendazim (50\% WP) & $0.005 \%$ & $4.100(16.33)$ & 78.32 \\
\hline $\mathrm{T}_{5}$ & Pyraclostrobin 5\%+ Mitiram 55\% & $0.20 \%$ & $3.534(12.00)$ & 84.07 \\
\hline $\mathrm{T}_{6}$ & Captan 70\%+ Hexaconazole 5\% & $0.20 \%$ & $3.891(14.67)$ & 80.52 \\
\hline $\mathrm{T}_{7}$ & Trichoderma harzianum & $5 \%$ & $5.016(24.67)$ & 67.25 \\
\hline $\mathrm{T}_{8}$ & Trichoderma viride & $5 \%$ & $6.337(39.67)$ & 47.33 \\
\hline $\mathrm{T}_{9}$ & Control & - & $8.708(75.33)$ & - \\
\hline & S. Em. \pm & & 0.08 & \\
\cline { 2 - 4 } & CD at 5\% & & 0.24 & \\
\cline { 2 - 4 } & CV \% & & 2.68 & \\
\end{tabular}

*Figures outside the parentheses indicate $\sqrt{x}+0.5$ transformation values

**Figures in parentheses indicate original values 


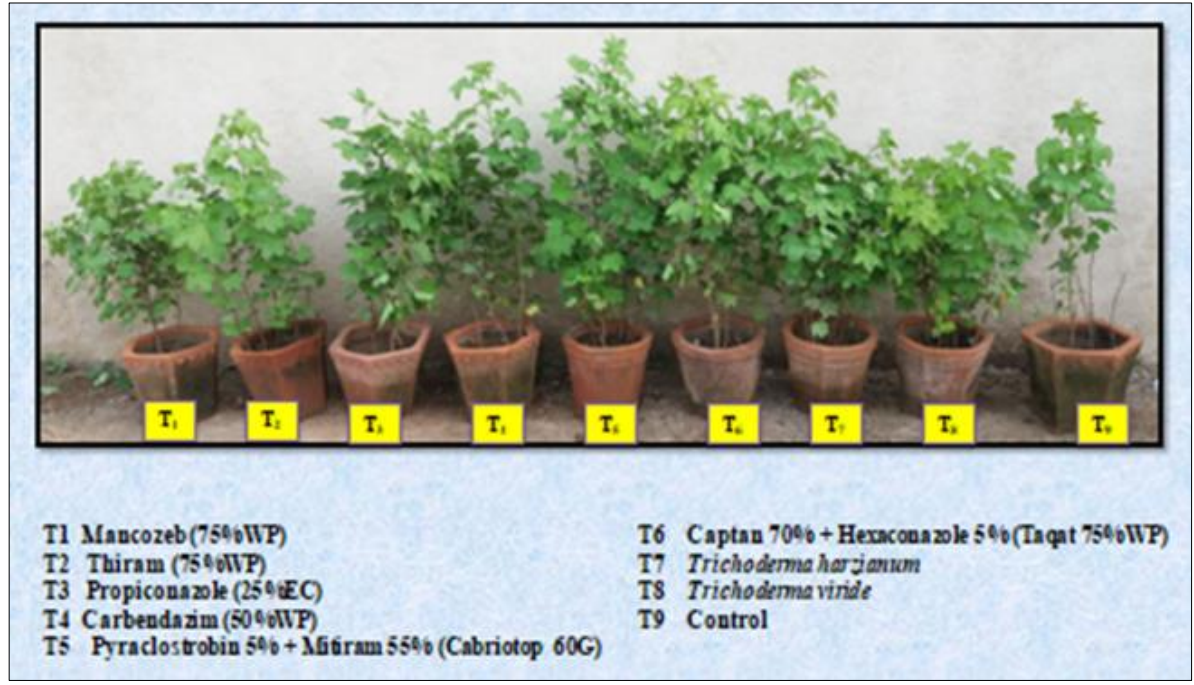

Plate 1: Testing of fungicides and bioagents for control of cotton wilt in pot conditions

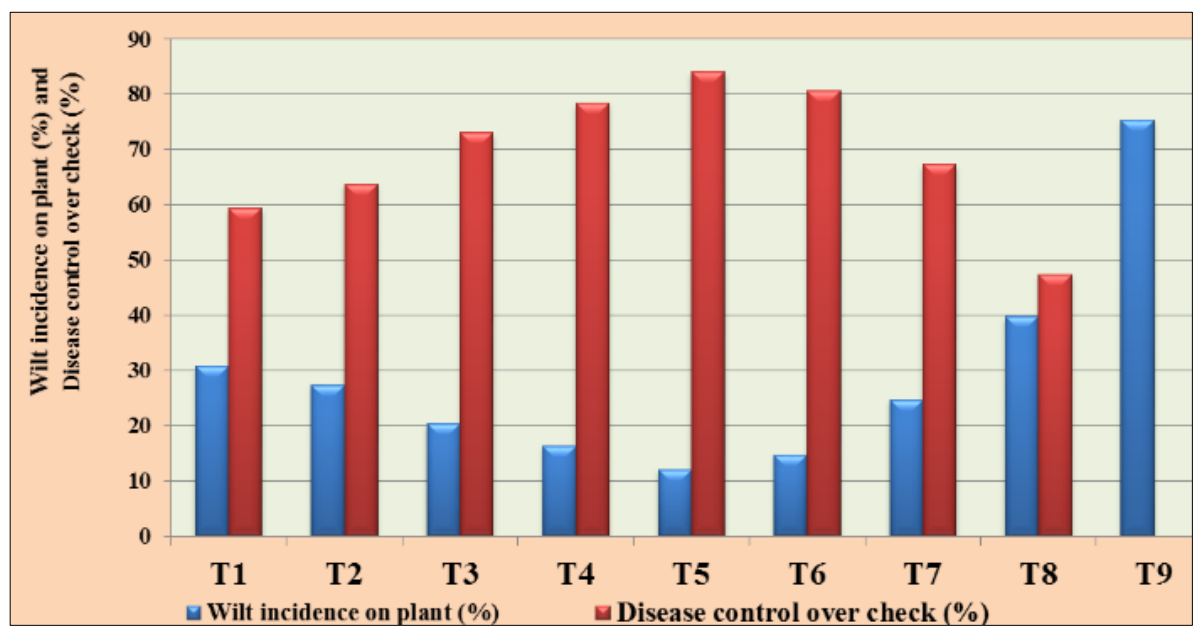

Fig 1: Showing wilt incidence on plant (\%) and Disease control over check (\%)

\section{Acknowledgement}

Author is highly thankful to Main Cotton Research Station (MCRS), NAU, Surat (Gujarat) and Department of Plant Pathology, N. M. College of Agriculture, NAU, Navsari for providing the required facility and other necessary arrangements for conducting the experiment in a sensible way. This research paper is a part of M.Sc. thesis submitted to Navsari Agricultural University (NAU), Navsari (Gujarat).

\section{References}

1. Bhattiprolu SL, Prasada Rao MP. Estimation of crop losses due to Alternaria leaf spot in cotton. Journal of Indian Society for Cotton Improvement 2009;14(2):151154.

2. Elsalam KA, Omar MR, Amal AA, Mansour MT, Hady A. Evaluation of a cotton germplasm collection against Fusarium wilt race 3 isolates from Egypt. Tropical Plant Pathology 2014;39(1):095-103.

3. Kushawah P. Symptomatology and management of fusarium wilt of cluster bean (Cyamopsis tetragonaloba L.). M.Sc. Thesis submitted to N.A.U., Navsari 2015.

4. Mayee CD, Mukewar PM. Loss-inducing diseases of cotton and their management with special reference to Andhra Pradesh. In Rao, N. G. P., Rao, A and Siddiq, E. A. (eds)- Cotton in Andhra Pradesh, Farm and Rural Science Foundation and ANGRAU, Hyderabad 2007, 197-199.
5. Monga D, Bhattiprolu SL, Prakash AH. Crop losses due to important cotton diseases. Central institute for cotton research, Nagpur, Technical Bulletin 2013, 9.

6. Monga D, Kranthi KR, Gopalakrishnan N, Mayee CD. World Cotton Research Conference-5, Mumbai 2011, 273-280.

7. Wheeler BEJ. An Introduction to Plant Disease. John Wiley and Sons Ltd., London 1969. 